Article

\title{
Physical Vulnerability and Local Responses to Flood Damage in Peri-Urban Areas of Dhaka, Bangladesh
}

\author{
Md. Nawrose Fatemi ${ }^{1, *}$, Seth Asare Okyere ${ }^{1}$, Stephen Kofi Diko ${ }^{2}$, Michihiro Kita ${ }^{1}$, \\ Motoki Shimoda ${ }^{1}$ and Shigeki Matsubara ${ }^{1}$ \\ 1 Division of Global Architecture, Osaka University, Suita, Osaka 565-0871, Japan; \\ seth_asare_okyere@arch.eng.osaka-u.ac.jp (S.A.O.); kita@arch.eng.osaka-u.ac.jp (M.K.); \\ shimoda@arch.eng.osaka-u.ac.jp (M.S.); shigeki@arch.eng.osaka-u.ac.jp (S.M.) \\ 2 Department of City and Regional Planning, University of Memphis, Memphis, TN 38152, USA; \\ skdiko@memphis.edu \\ * Correspondence: fatemi_nawrose@arch.eng.osaka-u.ac.jp
}

Received: 12 March 2020; Accepted: 8 May 2020; Published: 12 May 2020

check for updates

\begin{abstract}
In Eastern Dhaka, perennial flood remains a constant threat to people and livelihoods. Learning from the micro-level experiences of the poor in the peri-urban areas of Dhaka provides insights on the intersections between physical vulnerability, flood response strategies, and adaptive capacity. Through a convergent mixed method, this study examines the physical vulnerability of residential buildings, flood damages, and local physical responses in three neighborhoods of Eastern Dhaka. Results show that the level of damage to buildings is the most important predictor of physical vulnerability to floods. Buildings that are older than 20 years old and built with natural materials are likely to experience high flood damages compared to buildings that are less than 10 years and constructed with durable materials. The study concludes that in addition to socio-economic interventions, a targeted and people-centered flood management regime that pays attention to age, material composition, and structural quality of houses is necessary to build residents' adaptive capacities and long-term resilience to flooding. This study contributes to the emerging work on grassroots responses to flood vulnerabilities with practical insights for urban planners and disaster management professionals on particular interventions needed to improve the performance of local responses to flood risks and vulnerabilities.
\end{abstract}

Keywords: physical vulnerability; coping strategies; peri-urban area; Dhaka; Bangladesh

\section{Introduction}

The urban poor is often severely affected by environmental hazards due to their vulnerable physical location, poor housing quality, and limited capacity to prepare for, cope with and recover from extreme climatic events such as floods [1,2]. In developing countries, about $85 \%$ of households are estimated to be vulnerable to flooding [3-5]. As climate change impacts are projected to get severe, understanding people's real and perceived risks, their experiences, and response mechanisms are imperative, as they underpin the planning, design, and implementation of response strategies to curb the impact of flooding and efforts for building resilient communities [6-9]. People's experiences and response mechanisms to flooding are also relevant for transcending technical and engineering approaches to considering flood vulnerability as a socio-ecological issue [10-12].

Bangladesh is one of the world's most disaster-prone countries; it is ranked the ninth highest disaster risk country, according to the 2018 World Risk Index [13]. This ranking is informed by its high risk and vulnerability to climate change impacts and weak response capacities of both its residents and institutions. Perennial floods are the main disasters and environmental risks in Bangladesh—worsened 
by the frequent flooding of the 700 rivers, tributaries, and distributaries during the monsoon season. Altogether, these water bodies cover about $5 \%$ of the land surface and are about 22,155 km in length [14]. Bangladesh has approximately 163 million people and high population densities [15]. Juxtaposing this with the fact that a greater proportion of the population lives in floodplains, experiences with fluvial flooding and riverbank erosion is common among residents [16,17].

Its capital, Dhaka, is a megacity of 19.6 million people [18]. The city is surrounded mainly by six peripheral rivers (Turag and Buriganga on West, Balu and Sitalakhya on East, Tongi Khal to the North, and Dhaleshwari to the South), which overflow regularly during the monsoon season, making the city vulnerable to perennial fluvial flooding. This causes severe damages to buildings and infrastructure in both inner city and peri-urban areas-especially the eastern periphery that is yet to fully develop and urbanize [19]. However, in the last decade, this area around the capital has been experiencing rapid population and physical growth that has resulted in high densities and concentrations [20]. The need for affordable accommodation from population influx has resulted in encroachment in large portions of the floodplains of River Balu, reducing the efficiency of the natural system to deal with flooding. Not surprisingly, flooding has become a regular phenomenon at the eastern periphery of Dhaka.

Underpinned by this awareness, this paper investigates the vulnerability of the existing buildings to flood-related risk during the monsoon season in the eastern peri-urban areas of Dhaka city. Specifically, it examines the vulnerability of residential buildings to flooding, the extent of flood damage, and households' physical responses to flooding. Findings of this paper advance existing knowledge on household response strategies to perennial flooding and policy imperatives required to develop integrated flood risk management strategies in rapidly urbanizing cities.

\section{Flood Vulnerability and Response Strategies in Peri-Urban Areas}

\subsection{Flood Vulnerability and Flood Risk}

Floods are among the most recurring and devastating natural hazards that impact human lives, negatively causing severe economic burden throughout the world [21-23]. Recent projections suggest that flood risk will not subside in the future; rather due to climate change, its intensity and frequency will threaten many regions of the world and increase their vulnerability [24-27]. Both the flood characteristics (frequency, duration, and depth) and the vulnerability profile of an area determine the magnitude and scale of flood damage to that area [26]. In addition, factors such as physical infrastructure, geographic location, geomorphological setting, and people's cultural, political, and socio-economic condition of households influence the extent of their vulnerability to flooding. Thus, flood vulnerability and response strategies are underpinned by the intersections and interactions of social and environmental systems [28,29].

To examine flood vulnerability, it is important that the concept of 'vulnerability' is first addressed [30]. Vulnerability is a multi-dimensional concept, making it difficult to provide a single or absolute explanation to its meaning. [31]. In general, it encompasses the 'ability to respond to hazardous conditions' [p. xviii]. Vulnerability also reflects the 'characteristics of a person or group in terms of their capacity to anticipate, cope with, resist, and recover from the impact of the natural hazards' [32] (p. 11). The definition by Intergovernmental Panel on Climate Change (IPCC), much popularized in climate research, describes vulnerability as the degree to which a system is 'susceptible to, or unable to cope with, adverse effect of climate change' [33] (p. 881). From these definitions, the vulnerability can be conceptualized in the context of either the variation in exposure to hazards or the variation in humans' capacity to cope with hazards [34]. It is thus a spatiotemporal phenomenon-a dynamic event of space and time- -hazard-specific, and with physical, environmental, social, economic, and institutional dimensions [31].

This study focuses on vulnerability as it relates to the physical structures and components of the built environment that expose people and elements to specific natural hazards such as floods. Physical vulnerability, as it is called, results in physical loss and may influence the other dimensions of 
vulnerability such as social, economic, and institutional [35-37]. It is defined as 'the exposure to risk and inability to avoid or absorb potential harm in the built environment' (p. 5). According to the World Bank, 'physical vulnerability encompasses the structural and non-structural damage to buildings or building components or other infrastructure'. These damages could be direct, in terms of gradual and consistent deterioration of buildings and other infrastructure [38]. Flood damage on buildings are often extensive and deteriorates their material compositions and structures as well as their function [39]. The IPCC thus indicates that vulnerability encompasses a variety of concepts including sensitivity or susceptibility to harm and lack of capacity to cope and adapt. Therefore, information on the elements at risk (e.g., people; built environment; eco-systems), the exposure (e.g., proximity to the river; elevation of the area; frequency, duration, and depth of floods), and areas' susceptibility (e.g., socio-economic capacities, coping, and recovery) are essential for assessing physical damage due to flood [40].

In the extant literature, flood risks and damage to buildings are typically assessed in two ways: Empirical or analytical methods. Analytical methods use numerical models and computer simulation techniques to estimate the reliability of a structure and calculate its probability of failure as damage analysis, while empirical methods analyze damage data from the perspective of historical hazard events, or the opinion and previous experience of the flood victims [41]. However, Van Westen [42] emphasized an empirical method for its advantage of post-flood field survey. This method is particularly suited for flooding, which normally affects many buildings that are of the same type, and allows for a correlation between the hazard intensity and the degree of damage [38]. Other studies view flood vulnerability as a socio-ecological phenomenon and recommend integrating residents' experiences into unravelling flood damage and responses through interviews and surveys $[43,44]$. Cognizant of this, the study adopts the empirical method as it is suited to the geographical scope of the study (peri-urban), where urban consolidation is still on-going and required data for analytical methods are either hard to access or practically non-existent (see methodology below).

\subsection{Coping Capacity and Local Adaptation During Flooding}

In the literature on risk management and adaptation, the terms 'local coping capacity' and 'local adaptive capacity' are commonly used [45-47]. Though these two concepts use subtly different language, they describe similar activities [7]. Coping is made up of immediate and short-term measures to an event, culminating 'here and now' capacity of a system and/or community to mitigate and respond to an event [48]. According to the United Nations International Strategy for Disaster Reduction [46] (p. 8), it is 'the ability of people, organizations and systems, using available skills and resources, to face and manage adverse conditions, emergencies or disasters ... 'which can' ... contribute to the reduction of disaster risks'. Contrary to this, adaptation refers to long-term systematic processes of learning, experimentation, and adjustments before and after a disaster [49]. It is thus 'the ability of a system to adjust to climate change (including climate variability and extremes), to moderate potential damages, to take advantage of opportunities or cope with the consequences', according to the IPCC [50] (p. 21). Evidently, these concepts are context-specific, making the difference between them not clear cut. For this study, they are employed interchangeably as flood response strategies to encompass measures taken by individuals, households, and communities to reduce, manage, and adjust to their flood risks and vulnerabilities.

Peoples' response to flooding are varied including strategies adopted before, during, and after flood events [51-53]; they can also be 'preventive' (before the onset of an event) or 'mitigative' (during or post-flood measures). Typically, the intimate knowledge of hazards underpins viable response strategies [34]. This is often the basis of indigenous and local response strategies to flooding, which 'have been developed over hundreds of years, especially where people have had to colonize and cultivate new lands in flood plains' [32] (p. 134). At present, they are perceived as important avenues to develop and build individuals', households', and communities' ability to deal with their flooding vulnerabilities $[32,49,54,55]$. 
Studies have documented several ways of identifying response strategies among flood exposed populations, especially in low-income urban contexts [43,56]. Amoako [43] used field observations, informal interactions, group discussions, and mini-workshops to capture responses to flood disasters. Similarly, Jabeen et al. [7] used a combination of physical measurement of houses, sketches of house modifications, and livelihood assessments to unearth the physical, social, and economic aspects of flood response strategies. Often placed within the empirical method of flood studies, such mechanisms provide insights on experiential aspects of flood disasters to shed more light on the underpinnings behind quantitative results in the analytical method of flood vulnerability and damage assessment.

\subsection{Flood Response Strategies in Peri-Urban Areas}

Peri-urban by definition is an 'area where urban and rural features and processes meet, intertwine and interact, usually located between city and countryside' [57] (p. 122). They are not simply the periphery of cities but areas where both rural and urban features reconcile [58,59]. In many countries of the global south, peri-urban areas are not necessarily formal and regulated by metropolitan urban authorities; as a result, their development is often uncertain [60]. Characteristically, peri-urban settlers occupy river floodplains and engage in agrarian activities [61], as these areas are often unplanned. Their residents are also comparatively poor and disproportionately affected by flooding [62]. Consequently, these communities actively develop their response strategies to flood risks and vulnerabilities [63]. Strategies to deal with vulnerabilities associated with physical and the built environment in peri-urban areas operate at different scales including $[7,8,61]$ :

- Within the house: Raising furniture or building high furniture where people can rest during flooding, blocking entryways to prevent floodwater from entering into houses, and creating paths to direct the flow of water easily.

- Modifications to house structures: Installing rain-gutters, replacing walls, or supporting structures with flood-resistant materials such as bricks or concrete.

- Modifications around the house: Digging water channels, building dykes, laying sandbags.

- Improvements at the neighborhood level: Cleaning drains and canals, building retaining walls, and putting plastic sheets on the slopes.

In the global south, such strategies are more common, because the state is absent and market mechanisms are often dysfunctional or unreliable for the urban poor [64-66]. Nevertheless, to deal with flood challenges, government authorities need to understand and build on existing local flood response strategies [9]. Based on the foregoing, the conceptual framework below frames the intersections and interconnectedness between the core elements of flood risks or occurrence, emergent coping mechanisms, and their influence on flood impact (damage) and local adaptive capacity (Figure 1).

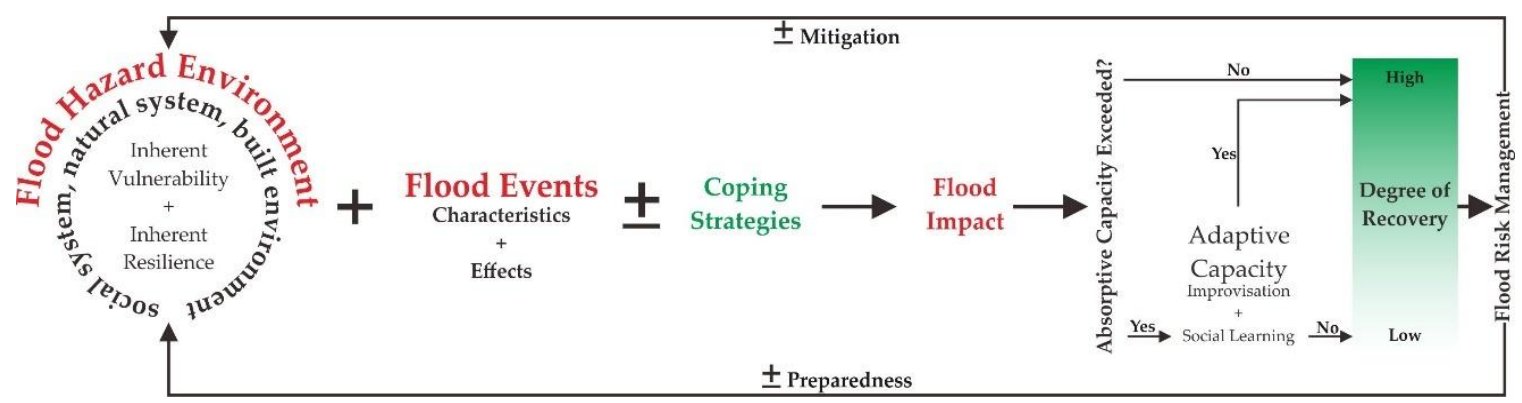

Figure 1. Conceptual framework explaining the relationship of flood vulnerability with coping strategies and flood risk management for a neighborhood (modified from DROP model [11]).

In Figure 1, as a socio-ecological phenomenon, the flood hazard environment encompasses place-specific factors, such as the social system, natural system, and the built environment. The degree of inherent vulnerability and resilience of any particular group or community at risk is highly 
influenced by these place-specific factors [11]. The built environment's exposure to flooding depends on factors such as building location and their specific design features, surrounding the land cover condition, plinth height, and other infrastructure (drainage system) [7]. During floods, the physical vulnerability of buildings also depends on proximity to rivers, elevation, along with the frequency, duration, and depth of floods [67]. Hence, effective coping strategies reduce flood impact and absence of coping strategies intensify flood impact. Absorptive capacity is enhanced when local coping strategies withstand the flood impact [30]. Nevertheless, if coping strategies are inadequate and flood impact is severe, then the physical damage will be beyond the absorptive capacity requiring the utilization of adaptive strategies developed through either improvisation or social learning to manage risk and recover from the flood events. Indeed, several studies $[3,7,68,69]$ highlight the need to build a detailed understanding of the scale and nature of local coping strategies to ensure adaptive capacity at household and community levels and to integrate them into disaster management plans.

\section{Materials and Methods}

\subsection{Study Design}

The research design is based on convergent parallel mixed methods research that utilizes quantitative and qualitative data collection and analytical techniques. The quantitative data is informed by Van Westen [41] empirical approach to assessing flood risk and damage through surveys. This approach was employed because the study area is peri-urban, informal, and at the initial stage of urban consolidation in Dhaka. As a result, hydrological and geomorphological data are unavailable to employ engineering and analytical methods. Nonetheless, coming from a socio-ecological systems perspective, employing the empirical method helps to integrate residents' experiences into understanding their flood vulnerability and response strategies $[43,44,56,70,71]$. As this method is reliant on time and the memory of flood victims, critics argue there is a high possibility residents may forget undocumented details at a later time [42]. Nonetheless, studies demonstrate that a combination of surveys with in-depth and critically triangulated interviews can generate reliable results $[40,43,45,72]$. In following these studies and given the acute lack of official documentation and data (e.g., topographical maps, hydrological data, etc.) and time and resource constraints, the empirical method was the most suitable. Subsequently, the empirical method provides an exploratory analysis to understand residents' experiences with flood risks and building damage embedded in the everyday life of those perennially confronted with flood disasters.

The convergent parallel mixed methods research process facilitated a methodological triangulation of the qualitative and quantitative methods on flooding and local response strategies in eastern Dhaka [73]. This method ensured the concurrent collection of qualitative and quantitative data during the research process, equal evaluation of the methods, and independent analysis and interpretation of the combined results [74]. Data were collected through a structured questionnaire survey, semi-structured informal interviews, transect walks and field observations, photographic documentation, videos, and sketches. The survey was conducted during the monsoon season between August and September of 2019.

\subsection{Study Settings}

This study was conducted in the eastern peri-urban areas of Dhaka city in Bangladesh. This study area selection was informed by three justifications. First, studies predict the current and future impacts of flooding to be more harmful and hazardous in developing countries such as Bangladesh $[75,76]$. Secondly, from a list of top 15 countries with the greatest population exposed to riverine flood risk, Bangladesh ranks second [77,78]. Bangladesh subsequently offers an avenue to explore flood response strategies that can be relevant to other developing countries. Third, although there is a vast body of scholarly work on flooding and coping strategies in Bangladesh $[7,53,56,79]$, scholars have paid little to no attention to the critical issues of physical vulnerability and its associated local response strategies 
in peri-urban Dhaka. More importantly, as urban growth and consolidation are occurring at the urban fringe areas where flood risks are pronounced, empirical engagement and a nuanced understanding of flood vulnerabilities and response strategies in such areas are critical to future sustainable urban development planning and management of Dhaka.

Eastern Dhaka is bounded by Dhaka Purbachal Road in the north, Pragati Sharani in the west, River Balu in the east and DND (Dhaka-Narayanganj-Demra) project area in the south. While Dhaka has a surface elevation ranging from 1 to $14 \mathrm{~m}$, land elevation ranges from 2 to $5 \mathrm{~m}$ in eastern Dhaka-becoming close to zero near the River Balu [80]. It also experiences similar rainfall patterns as Dhaka city, which has an annual rainfall of about $2000 \mathrm{~mm}$, with $80 \%$ occurring during the monsoon season from June to October [81]. Eastern Dhaka is mainly rural with the vast expanse of agricultural lands along the floodplain of River Balu [19,82]. It is nearly 119 square kilometers and lies in the low-lying area of the city. Due to this, it floods frequently and continues to be at severe risk of flooding. Eastern Dhaka also has a network of natural canals that helps to drain and discharge stormwater run-off accumulation from the main city as well as within the area into River Balu [83]. Despite this natural system, flooding remains a challenge. This informs the Dhaka Flood Control and Storm Water Drainage Master Plan, which aims to prevent and protect this peri-urban area against fluvial flood by building compartments (D1, D2, and D3), pumped drainage facilities and retention pond areas [80,84]. The study focuses on the lower compartment of D3 (Figure 2).

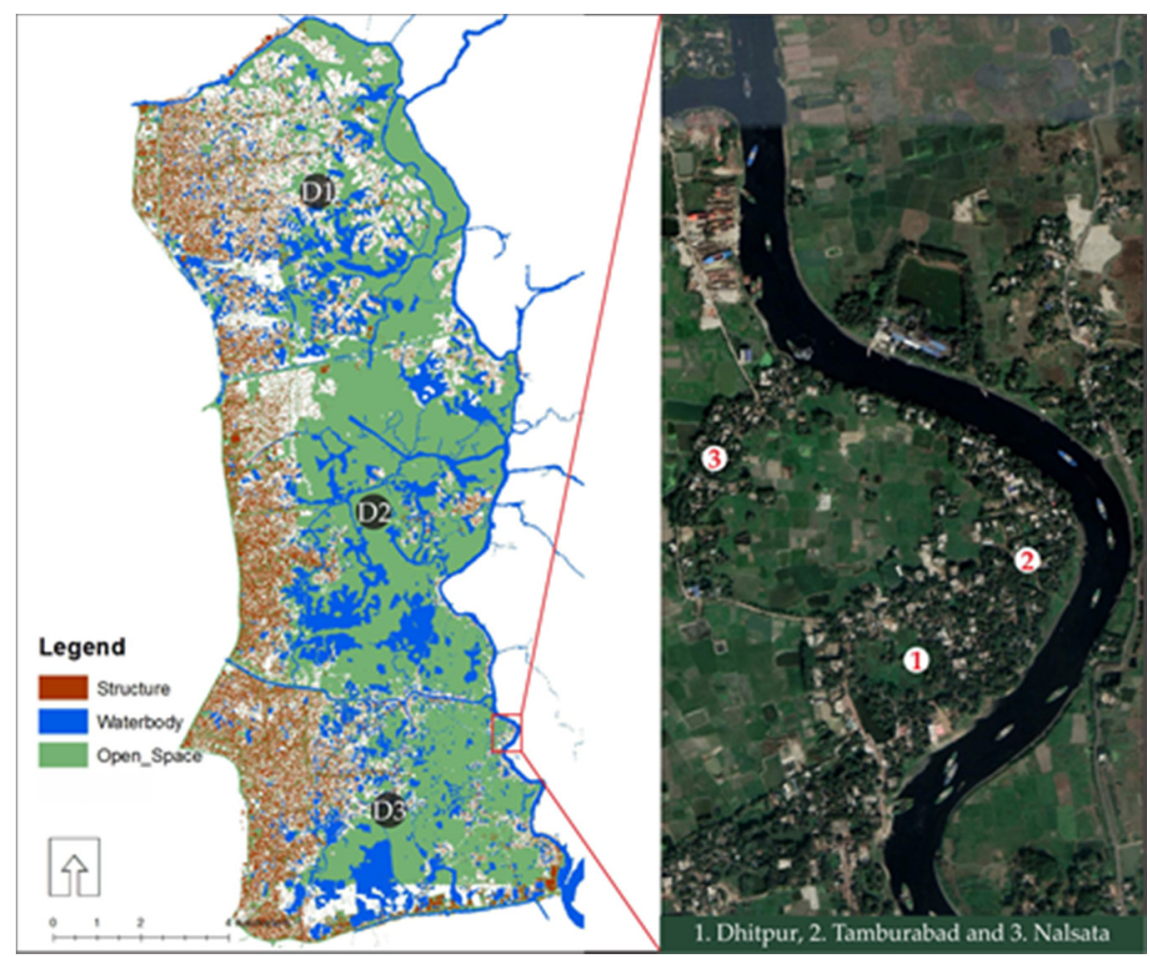

Figure 2. Location map of the study area in Eastern Fringe (D3) and study area in Google Map.

The study area chosen for this research is about $7.5 \mathrm{~km}$ from the city core and under the jurisdiction of Khilgaon Thana (Thana meaning 'sub-districts' in Bengali). The major land use categories are agricultural $(42.65 \%)$, residential $(26.65 \%)$, other facilities $(5.53 \%)$, vacant land $(7.52 \%)$, and water bodies (17.49\%). The area has three different mahallas (meaning 'neighborhoods' in Bengali) with each consisting of 180-220 households. This paper uses surveyed data from these three mahallas (Figure 2) namely, Dhitpur (M1), Tamburabad (M2), and Nalsata (M3). These study areas are appropriate due to the high vulnerability to flooding $[80,81,85]$. 


\subsection{Sampling and Data Collection}

For the questionnaire survey, the sampling was done at the household level of flood-affected eastern peri-urban areas of Khilgaon Thana in Dhaka. Questionnaires were administered in three mahallas (Figure 2)—Dhitpur (M1), Tamburabad (M2), and Nalsata (M3)—selected based on their previous experience with flooding, the age of settlements, and proximity to the Balu river. The total number of houses in those three mahallas was 286 (in Dhitpur, 105 houses; in Tamburabad, 104 houses; and in Nalsata, 77 houses). In each mahalla, between 30 and 35 houses were selected for the questionnaire survey. In total, 100 houses were surveyed (in Dhitpur, 35 houses out of 105; in Tamburabad, 35 houses out of 104; and in Nalsata, 30 houses out of 77) (Table 1). The questionnaire survey was conducted in the three mahallas with household heads or the oldest member of the household in each house. To administer the questionnaire, each mahalla was divided into three zones where houses were selected based on the willingness and availability of the household head or oldest member to be interviewed.

Table 1. Demographic profile and composition of households' in three neighborhoods.

\begin{tabular}{ccc}
\hline Parameters & Number & $\%$ \\
\hline Number of households & 100 & - \\
Number of total populations & 575 & - \\
\hline Gender & & $52 \%$ \\
Male & 300 & $48 \%$ \\
Female & 275 & \\
Age & & $29 \%$ \\
Children (0-14 years) & 165 & $13 \%$ \\
Early Working Group (15-24 years) & 73 & $42 \%$ \\
Prime Working Group (25-54 years) & 242 & $10 \%$ \\
Mature Working Group (54-65 years) & 58 & $6 \%$ \\
Elderly (>65 years) & 37 & \\
\hline
\end{tabular}

Following the questionnaire survey, 30 semi-structured informal interviews were also conducted with household heads. These informal interviews were conducted to clarify the results from the questionnaire survey (e.g., flood return period, flood depth, flood damage to houses, adjustments to buildings after floods, and recovery). In each mahalla, nine informal interviews were conducted with residents and one discussion with the community leader. Data from community leaders provided avenues to compare earlier information and to seek clarification where necessary. The informal interviews were recorded in Bengali (local language) and lasted about 30 minutes. Photographs were taken to document evidence of physical damages and local response strategies.

\subsection{Study Variables}

A physical vulnerability study has to consider several variables within an area such as: Main construction material for the roof, walls, and floor (building typology) [36,86-88]; the position of buildings in relation to the street level (plinth height) [86,89] building; the age of household residence [36,88]; availability of flood protection measures on building (building modifications) [86,89]. In this study, the physical vulnerability was measured using flood damage as the variable. In addition to demographic variables, those above-mentioned four variables were used to measure the characteristics of buildings in the study areas.

The extent of flood damage was coded as $0=$ no damage, $1=$ low damage, $2=$ medium, and $3=$ high damage. Building typology was grouped as $1=$ buildings built with natural materials (mud, bamboo etc.), 2 = buildings built with temporary materials (corrugated metal sheet, wood etc.), and $3=$ buildings built with durable materials (brick, concrete etc.). Age of the building was categorized as $1=0-5$ years, $2=6-10$ years, $3=11-15$ years, $4=16-20$ years, and $5=$ above 21 years. The plinth 
height of the building was defined as $1=0.1-0.25 \mathrm{~m}, 2=0.26-0.5 \mathrm{~m}, 3=0.51-0.75 \mathrm{~m}, 4=0.76-1 \mathrm{~m}$, and $5=$ above $1 \mathrm{~m}$. Finally, in addressing the physical vulnerability to flooding, respondents modified their residential buildings in various ways, which were categorized as $1=$ Raised homestead, $2=$ Raised Plinth level, 3 = Strengthened Plinth, $4=$ Strengthened walls, and $5=$ Strengthened whole house.

\subsection{Data Analysis}

The interview data were analyzed using thematic content analysis where responses were grouped according to themes and their relation to results from the quantitative data. The questionnaire survey data were collated and analyzed using SPSS version 23 (Statistical Package for Social Sciences) and Microsoft Excel. Statistical analysis using cross tabulation through Cramer's V in SPSS was performed to examine relationships between variables. Generally, when Cramer's $\mathrm{V}<0.1$, there is weak correlation; $<0.3$, there is modest correlation; $<0.5$, there is moderate correlation; $<0.8$, there is strong correlation; and $<1$, there is a very strong correlation. This paper employs $p$-value $<0.05$ as the test for statistical significance. Descriptive statistics in the form of percentages and frequencies were presented in the form of tables, charts, and graphs. Additionally, a two-step cluster analysis was performed to examine the interconnections among variables $[90,91]$.

\section{Results}

\subsection{Demographic and Socio-Economic Profile of the Households}

The results of the study reveal that among the total 575 household members in the 100 surveyed households, $52 \%$ were male and $48 \%$ were female (Table 1). This is consistent with the national male-female ratio (1: 0.94), according to the Bangladesh Bureau of Statistics [92]. Approximately, $42 \%$ of household members in the surveyed households were between 25 and 54 years, suggesting that a large portion of the flood victims are within the economically active age cohort.

However, the elderly (above 65 years) accounted for $6 \%$, while $29 \%$ were children (between 0 and 14 years). These are also quite consistent with the national age structure (children $26.5 \%$, early working group $18.5 \%$, prime working group $41 \%$, mature working group $7.5 \%$, and elderly $6.5 \%$ ) [93]. Generally, about one-third of the members within the surveyed households were children (29\%) and the elderly (6\%)-those usually considered as the cohort highly vulnerable to floods [94]. Also, the mean household size was 5.75 members, while the majority of the sampled population (61\%) lived in households with between 4 and 6 members. About 21\% had large family sizes; households with 7-9 persons constituted $11 \%$ and households with above 10 persons were $10 \%$. Such large household sizes, with a high number of dependents, often have high consumption expenditures and lower savings [95].

The highest level of education for most household heads was primary education (43\%) and $18 \%$ had no formal education (Table 2). The predominant economic activity was farming and artisanship, respectively, at $28 \%$ and $30 \%$. Only $3 \%$ of the respondents were in civil service, while $3 \%$ of respondents were unemployed. Nonetheless, all those interviewed reported some income that is either connected to their occupation or non-occupation sources such as selling milk from cattle owned by the household in the case of housewives and unemployed. From those interviewed, $67 \%$ of them earn a monthly income of 5000-13,200 BDT and 24\% earn 13,201-25,000 BDT. The lower-income status of respondents is worrying as low-income people suffer the most from natural hazards and have the least capacities to respond to short- to long-term flood risks and vulnerabilities compared to those in the higher income bracket [96]. 
Table 2. Socio-economic characteristics of household heads' in three neighborhoods $(\mathrm{N}=100)$.

\begin{tabular}{|c|c|c|c|c|c|}
\hline Parameters & Number & $\%$ & Parameters & Number & $\%$ \\
\hline Household Size & & & $\begin{array}{l}\text { Education } \\
\text { Level }\end{array}$ & & \\
\hline $1-3$ members & 18 & 18 & $\begin{array}{l}\text { No formal } \\
\text { Education }\end{array}$ & 18 & 18 \\
\hline 4-6 members & 61 & 61 & $\begin{array}{l}\text { Primary } \\
\text { Education }\end{array}$ & 43 & 43 \\
\hline 7-9 members & 11 & 11 & $\begin{array}{l}\text { Secondary } \\
\text { Education }\end{array}$ & 29 & 29 \\
\hline $10+$ members & 10 & 10 & $\begin{array}{l}\text { Tertiary } \\
\text { Education }\end{array}$ & 10 & 10 \\
\hline Monthly Income (BDT) & & & Occupation & & \\
\hline Marginal $(<5000)$ & 0 & 0 & Farmer & 28 & 28 \\
\hline Low $(5000-13,200)$ & 67 & 67 & Housewife & 31 & 31 \\
\hline Lower-middle $(13,201-25,000)$ & 24 & 24 & Artisan & 30 & 30 \\
\hline Middle $(25,001-50,000)$ & 6 & 6 & Civil service & 3 & 3 \\
\hline Upper-middle $(50,001-100,000)$ & 3 & 3 & Unemployed & 3 & 3 \\
\hline High $(>100,000)$ & 0 & 0 & Other & 5 & 5 \\
\hline
\end{tabular}

1 USD = 85 BDT (7 February, 2020).

\subsection{Causes of Flood}

In total, $48 \%$ of the respondents indicated overflow from River Balu as the cause of flooding, $29 \%$ indicated close proximity to River Balu, 13\% reported heavy rainfall, and 10\% emphasized the inadequacy of the drainage or blockage in canals as the reason for inundation. However, there exist differences in respondents' understanding of the causes of flooding across the study area. In Dhitpur and Nalsata for instance, $40 \%$ and $87 \%$ of respondents respectively indicated the overflow of River Balu as the prime cause of flooding, while $71 \%$ in Tamburabad emphasized close proximity of their houses along 'River Balu' as the main cause (Table 3). A community leader summarizes the causes of flooding as follows:

'During the monsoon season, heavy rainfall is an obvious event. As in the whole area, we do not have proper drainage systems, all the low-lying farmlands start to submerge with water. Moreover, stormwater from the city comes through the canals, but due to the waste dumping and landfilling in those canals, they become stagnant. Therefore, stormwater also overflow into our farmlands. And the worst happens when the river water exceeds the danger level and worsens the impact.' (Community Leader A, Dhitpur, Age 48)

Table 3. Community perceptions on causes of the inundation in studied areas.

\begin{tabular}{lcccccccc}
\hline \multirow{2}{*}{$\begin{array}{l}\text { Major Causes of } \\
\text { Flooding }\end{array}$} & \multicolumn{2}{c}{$\begin{array}{c}\text { M1: } \\
\text { Dhitpur }\end{array}$} & \multicolumn{2}{c}{$\begin{array}{c}\text { M2: } \\
\text { Tamburabad }\end{array}$} & \multicolumn{2}{c}{$\begin{array}{c}\text { M3: } \\
\text { Nalsata }\end{array}$} & \multicolumn{2}{c}{$\begin{array}{c}\text { Total } \\
(\mathbf{N}=\mathbf{1 0 0})\end{array}$} \\
\cline { 2 - 11 } & no. & $\mathbf{\%}$ & no. & $\mathbf{\%}$ & no. & $\mathbf{\%}$ & no. & \% \\
\hline Heavy Rainfall & 11 & 31 & 2 & 6 & 0 & 0 & 13 & 13 \\
\hline Overflow from River & 14 & 40 & 8 & 23 & 26 & 87 & 48 & 48 \\
\hline $\begin{array}{l}\text { Building on Flood } \\
\text { Plains }\end{array}$ & 0 & 0 & 25 & 71 & 4 & 13 & 29 & 29 \\
\hline $\begin{array}{l}\text { Inadequacy of Drainage } \\
\text { or Blockage in Canals }\end{array}$ & 10 & 29 & 0 & 0 & 0 & 0 & 10 & 10 \\
\hline Total & 35 & 100 & 35 & 100 & 30 & 100 & 100 & 100 \\
\hline
\end{tabular}




\subsection{Flood Damage to Residential Buildings}

The physical vulnerability, measured as the extent of flood damage to residential buildings, was compared to five building attributes namely: Building age, building typology, plinth height, building modifications to control the floodwater. This provided insight into the variations in physical vulnerability based on these different building attributes. The results from Cramer's V analysis revealed a modest to statistically significant (P-value $<0.05$ ) relationship between the variables (Table 4 ). Hence, these attributes influence the degree to which buildings are damaged by flooding in each Mahalla.

Table 4. The relationships between building attributes and flood damage.

\begin{tabular}{lccc}
\hline \multirow{2}{*}{ Variables } & \multicolumn{2}{c}{ Cramer's V } & \multirow{2}{*}{ N of Valid Cases } \\
\cline { 2 - 3 } & Value & Approx. Sig. & \\
\hline Building Typology & 0.329 & 0.000 & 100 \\
\hline Age of the Buildings & 0.399 & 0.000 & 100 \\
\hline Height of Plinth & 0.341 & 0.003 & 100 \\
\hline Building Modifications & 0.425 & 0.000 & 100 \\
\hline
\end{tabular}

The level of damage was measured using a Likert Scale: No damage, low damage (plot, ground surface elements, boundary walls are affected), medium damage (plinth level and first floor walls along with low damage elements are affected), and high damage (building interior, furniture along with medium and low damage components are affected). All respondents reported some form of damage albeit at different extents (Figure 3). In Dhitpur, 46\% reported low damage, 28\% was medium damage, and $26 \%$ was high damage of buildings in their neighborhood. In Tamburabad, $54 \%$ reported high damage, while medium damage was $40 \%$ and low damage was only $6 \%$. In Nalsata, those who reported low damage, medium damage, and high damage constituted $43 \%, 27 \%$, and $30 \%$, respectively.

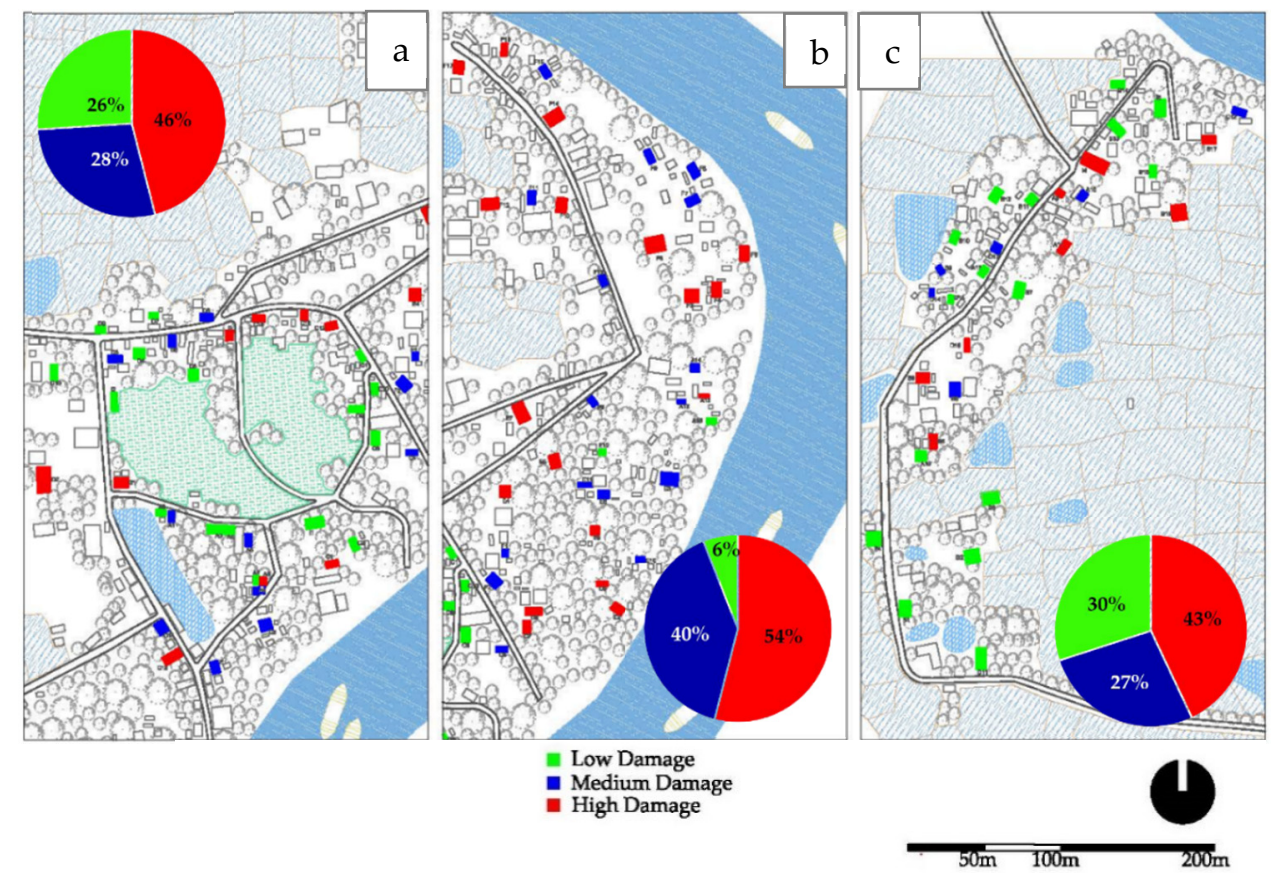

Figure 3. Various extents of damage to the buildings in three neighborhoods. (a) Dhitpur, (b) Tamburabad (c) Nalsata. 


\subsubsection{Flood Damage and Building Typology}

Three types of buildings were identified based on their construction materials. They are buildings built with (i) natural materials (mud, bamboo etc.), (ii) temporary materials (corrugated metal sheet, wood etc.), and (iii) durable materials (brick, concrete etc.). The extent of physical vulnerability to flooding was dependent on the type of building materials (Table 4) and as one interviewee observes:

'Those houses built of mud and bamboo are easily damaged or even washed away during the flood. In most of our houses, building materials are also not resistant to floodwater. Therefore, prolonged flood events caused irreparable damage to them. The houses along the river are in a more hazardous condition. When river water rises suddenly within the night, living in those houses becomes unsafe. The river erosion during the monsoon season also makes our lives challenging. Many people lost a portion of their land properties due to erosion.' (Old resident, Tamburabad, Age 67)

Buildings with durable materials experience low damage compared with those constructed with temporary and natural materials. This result was statistically significant $(p=0.000)$, with modest correlations (Cramer's V $=0.329$ ) (Table 5). Specifically, $80 \%$ of buildings with natural materials reported high damage compared to $31.6 \%$ of buildings with temporary materials and $21.4 \%$ of buildings with durable materials (Table 5).

Table 5. Building typology and damage due to flooding.

\begin{tabular}{lcccccccc}
\hline & \multicolumn{7}{c}{ Building Typology } \\
\cline { 2 - 9 } $\begin{array}{l}\text { Damage due to } \\
\text { Flooding }\end{array}$ & $\begin{array}{c}\text { Buildings with } \\
\text { Natural Materials }\end{array}$ & $\begin{array}{c}\text { Buildings with } \\
\text { Temporary Materials }\end{array}$ & $\begin{array}{c}\text { Buildings with } \\
\text { Durable Material }\end{array}$ & Total \\
\cline { 2 - 10 } & No. & $\%$ & No. & $\%$ & No. & $\%$ & No. & $\%$ \\
\hline Low Damage & 1 & 5.0 & 12 & 31.6 & 18 & 42.9 & 31 & 31 \\
\hline Medium Damage & 3 & 15.0 & 14 & 36.8 & 15 & 35.7 & 32 & 32 \\
\hline High Damage & 16 & 80.0 & 12 & 31.6 & 9 & 21.4 & 37 & 37 \\
\hline Total & 20 & 100 & 38 & 100 & 42 & 100 & 100 & 100 \\
\hline
\end{tabular}

\subsubsection{Flood Damage and Age of the Buildings}

The age of the buildings was considered in five-year intervals where the newest was $0-5$ years and above 21 years was the oldest (Table 6). The relationship between flood damage and the age of the building was statistically significant with modest Cramer V's of 0.399 (Table 4). From the analysis, $64.3 \%$ of buildings $0-5$ years had low damage, $58.3 \%$ for $6-10$ years, $8.3 \%$ for $11-15$ years, and $7.7 \%$ for $16-20$ years, and $16.2 \%$ for buildings 21 years and above. Similarly, buildings with the highest proportions of damage were those that were older, increasing from $14.3 \%$ to $56.8 \%$ for buildings $0-5$ years old and 21 years and above, respectively (Table 6).

Table 6. Age of residential buildings and damage due to flooding.

\begin{tabular}{|c|c|c|c|c|c|c|c|c|c|c|c|c|}
\hline \multirow{3}{*}{$\begin{array}{l}\text { Damage Due to } \\
\text { Flooding }\end{array}$} & \multicolumn{12}{|c|}{ Age of The Building } \\
\hline & \multicolumn{2}{|c|}{ 0-5 Years } & \multicolumn{2}{|c|}{ 6-10 Years } & \multicolumn{2}{|c|}{ 11-15 Years } & \multicolumn{2}{|c|}{ 16-20 Years } & \multicolumn{2}{|c|}{$21+$ Years } & \multicolumn{2}{|c|}{ Total } \\
\hline & No. & $\%$ & No. & $\%$ & No. & $\%$ & No. & $\%$ & No. & $\%$ & No. & $\%$ \\
\hline Low Damage & 9 & 64.3 & 14 & 58.3 & 1 & 8.3 & 1 & 7.7 & 6 & 16.2 & 31 & 31 \\
\hline Medium Damage & 3 & 21.4 & 5 & 20.8 & 8 & 66.7 & 6 & 46.2 & 10 & 27.0 & 32 & 32 \\
\hline High Damage & 2 & 14.3 & 5 & 20.8 & 3 & 25.0 & 6 & 46.2 & 21 & 56.8 & 37 & 37 \\
\hline Total & 14 & 100 & 24 & 100 & 12 & 100 & 13 & 100 & 37 & 100 & 100 & 100 \\
\hline
\end{tabular}




\subsubsection{Flood Damage and the Height of Plinth Level}

The plinth height of buildings was measured in five categories using intervals of $0.25 \mathrm{~m}$ starting from $0.1 \mathrm{~m}$ and ending with 'above $1 \mathrm{~m}$ '. The analysis confirmed that there is a statistically significant modest relationship (Cramer's V $=0.341$ ) between the Plinth height and the damage extent from flooding (Table 4).

From Table 7, 70\% of buildings with plinth height between $0.1-0.25 \mathrm{~m}$ experienced high damages. This proportion declined as the plinth height increased with no record of high damage with plinth height of $1 \mathrm{~m}$ and above. At the same time, when plinth height is between $0.1-0.25 \mathrm{~m}, 10.0 \%$ of respondents report low damage. The proportion of low damage to buildings increased as the plinth height rises with $26.5 \%$ for $0.26-0.5 \mathrm{~m}, 22.6 \%$ for $0.51-0.75 \mathrm{~m}, 38.9 \%$ for $0.76-1 \mathrm{~m}$, and $100 \%$ for plinth height of $1 \mathrm{~m}$ and above (Table 8). Akin with other building attributes such as building materials and age of building, this study reveals that the extent of damage from flooding is dependent on plinth height, which provides some insight into the subsequent discussions on flood response strategies by respondents.

Table 7. Plinth height of the building and damage due to flooding.

\begin{tabular}{|c|c|c|c|c|c|c|c|c|c|c|c|c|}
\hline \multirow{3}{*}{$\begin{array}{l}\text { Damage Due to } \\
\text { Flooding }\end{array}$} & \multicolumn{12}{|c|}{ Plinth Height of the Building } \\
\hline & \multicolumn{2}{|c|}{$0.1-0.25 \mathrm{~m}$} & \multicolumn{2}{|c|}{$0.26-0.5 \mathrm{~m}$} & \multicolumn{2}{|c|}{$0.51-0.75 \mathrm{~m}$} & \multicolumn{2}{|c|}{$0.76-1 \mathrm{~m}$} & \multicolumn{2}{|c|}{ Above $1 \mathrm{~m}$} & \multicolumn{2}{|c|}{ Total } \\
\hline & No. & $\%$ & No. & $\%$ & No. & $\%$ & No. & $\%$ & No. & $\%$ & No. & $\%$ \\
\hline Low Damage & 1 & 10.0 & 9 & 26.5 & 7 & 22.6 & 7 & 38.9 & 7 & 100 & 31 & 31 \\
\hline Medium Damage & 2 & 20.0 & 11 & 32.4 & 13 & 41.9 & 6 & 33.3 & 0 & 0.0 & 32 & 32 \\
\hline High Damage & 7 & 70.0 & 14 & 41.2 & 11 & 35.5 & 5 & 27.8 & 0 & 0.0 & 37 & 37 \\
\hline Total & 10 & 100 & 34 & 100 & 31 & 100 & 18 & 100 & 7 & 100 & 100 & 100 \\
\hline
\end{tabular}

Table 8. Modified parts of the buildings and damage due to flooding.

\begin{tabular}{|c|c|c|c|c|c|c|c|c|c|c|c|c|}
\hline \multirow{3}{*}{$\begin{array}{l}\text { Damage Due to } \\
\text { Flooding }\end{array}$} & \multicolumn{12}{|c|}{ Type of Modifications of the Houses } \\
\hline & \multicolumn{2}{|c|}{$\begin{array}{c}\text { Raised } \\
\text { Homestead }\end{array}$} & \multicolumn{2}{|c|}{$\begin{array}{c}\text { Raised Plinth } \\
\text { Height }\end{array}$} & \multicolumn{2}{|c|}{$\begin{array}{l}\text { Strengthened } \\
\text { Plinth }\end{array}$} & \multicolumn{2}{|c|}{$\begin{array}{l}\text { Strengthened } \\
\text { Walls }\end{array}$} & \multicolumn{2}{|c|}{$\begin{array}{l}\text { Strengthened } \\
\text { Whole House }\end{array}$} & \multicolumn{2}{|c|}{ Total } \\
\hline & No. & $\%$ & No. & $\%$ & No. & $\%$ & No. & $\%$ & No. & $\%$ & No. & $\%$ \\
\hline Low Damage & 8 & 100 & 9 & 40.9 & 7 & 41.2 & 6 & 23.1 & 1 & 3.7 & 31 & 31 \\
\hline Medium Damage & 0 & 0 & 8 & 36.4 & 4 & 23.5 & 12 & 46.2 & 8 & 29.6 & 32 & 32 \\
\hline High Damage & 0 & 0 & 5 & 22.7 & 6 & 35.3 & 8 & 30.8 & 18 & 66.7 & 37 & 37 \\
\hline Total & 8 & 100 & 22 & 100 & 17 & 100 & 26 & 100 & 27 & 100 & 100 & 100 \\
\hline
\end{tabular}

\subsection{Physical Response to Flooding}

\subsubsection{Building Modifications}

The most common action by respondents to address the physical vulnerability to perennial flooding was through modifications of residential buildings, by raising homestead and plinth level, strengthening the plinth and building walls, as well as strengthening the whole building. Here, 'strengthen' means residents changing the existing non-resistant material with a flood-resistant and durable material. A respondent from Dhitpur narrated that:

'To protect our houses from regular flooding, we try to strengthen our houses, when we can. Raising the plinth height or strengthening the foundation is a very common modifications for us; it helps us protect our houses from the penetration of floodwater. Even a few of us renovate the whole structure with durable material. But all (of us) are not financially affluent enough and cannot save a lot to have a strong house within a short period.' (Farmer, Dhitpur, Age 42) 
The data analysis reveals that there is a statistically significant modest association (Cramer's $\mathrm{V}=0.425, p=0.000$ ) between physical modifications and damage to flooding (Table 4). While the primary goal of these modifications at the building level was to address the physical vulnerability of residential buildings to flooding, the nature of these modifications is dependent on the extent of flood damage. For instance, all respondents who raised their homestead by erecting and constructing barriers with mud/brick in their surroundings above the road level only experience low damage during floods compared to $66.7 \%$ of respondents who modified their entire building because they experienced high damages to their buildings from flooding (Table 8). Respondents' actions through building modification demonstrate residents' awareness of their physical vulnerability to flood and agency to prevent flood disaster.

\subsubsection{Use of Flood-Resistant Building Materials}

Respondents also changed building materials for building floors, walls, and roofs in response to their physical vulnerability to flooding. Although some forms of modifications are being undertaken to buildings to address flood damage, the materials used for the construction of plinths, floors, wall, and roofs by some respondents cannot withstand a prolonged flood event. The study finds that $20 \%$ of interviewees reported using mud to construct their foundations, whereas 15\% used untreated bamboo for their walls (Figure 4). Assessments using the technical suitability determinants (TSD) of buildings materials to flooding by the Federal Emergency Management Agency (Table 9) shows that some materials used for construction cannot withstand a prolonged flood event, thus increasing the physical vulnerability of those who use these materials for flooding. However, it needs mentioning that the low resistance of existing building materials to flood damage does not necessarily translate into a lack of awareness about high-resistance materials among respondents. On the contrary, respondents were knowledgeable as to which materials afforded better resistance to flood damage. As one respondent noted vividly:

'We experienced that brick or masonry houses are stronger than mud houses. But at first, people try to change their plinth material, and then the wall of the house. For roofs, the popular choice is corrugated steel, as it is cheaper (than RCC roof), easy to install and any panel can be changed, if it gets damaged.'

(Craftsman, Tamburabad, Age 50)

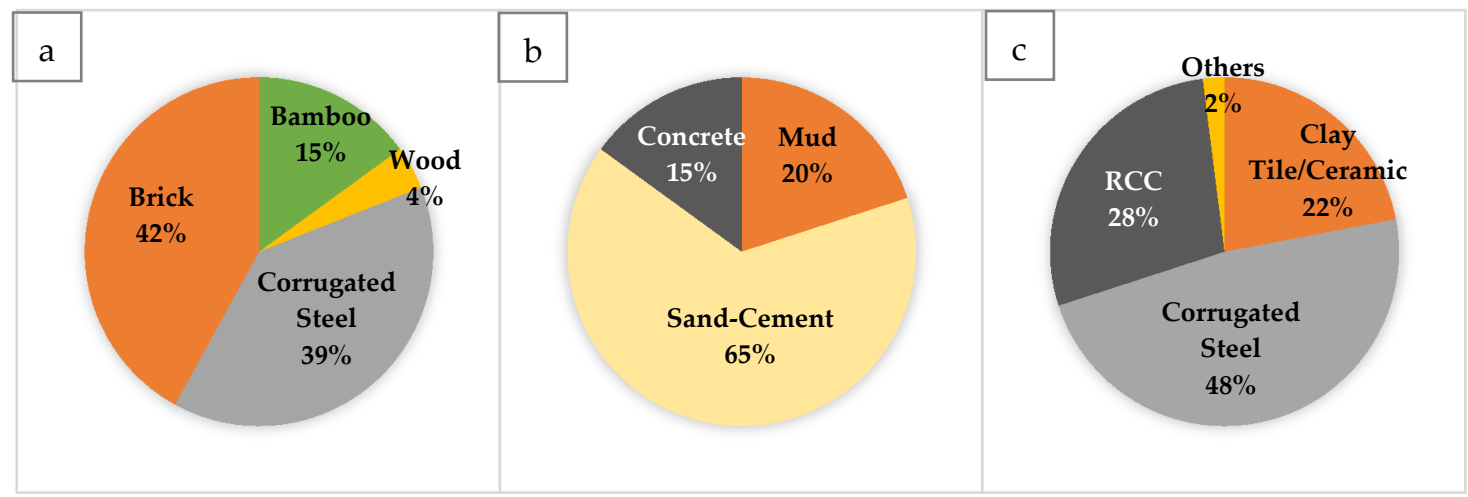

Figure 4. (a) Percentage of material used in foundation and plinth; (b) percentage of wall material; (c) percentage of roof material. 
Table 9. Assessment of building materials in relation to flood resistance.

\begin{tabular}{|c|c|c|c|c|c|}
\hline \multirow{2}{*}{$\begin{array}{l}\text { Building Material } \\
\text { Categories }\end{array}$} & \multirow{2}{*}{$\begin{array}{c}\text { Building } \\
\text { Material Type }\end{array}$} & \multicolumn{3}{|c|}{ Technical Suitability ${ }^{1}$} & \multirow{2}{*}{$\begin{array}{l}\text { Percentage of the } \\
\text { Respondents }\end{array}$} \\
\hline & & Resistant & $\begin{array}{l}\text { Resistant to } \\
\text { Some Extent }\end{array}$ & Non-Resistant & \\
\hline \multirow{3}{*}{$\begin{array}{l}\text { Foundation and } \\
\text { plinth }\end{array}$} & Mud & - & - & $\bullet$ & $20 \%$ \\
\hline & Sand-cement & - & $\bullet$ & - & $65 \%$ \\
\hline & Concrete & $\bullet$ & - & & $15 \%$ \\
\hline \multirow{4}{*}{ Wall } & Bamboo & - & - & • & $15 \%$ \\
\hline & Wood & - & - & $\bullet$ & $4 \%$ \\
\hline & Corrugated & - & $\bullet$ & - & $39 \%$ \\
\hline & $\begin{array}{l}\text { Steel } \\
\text { Brick }\end{array}$ & - & • & - & $42 \%$ \\
\hline \multirow{4}{*}{ Roof } & Clay tile & $\bullet$ & & & $22 \%$ \\
\hline & $\begin{array}{l}\text { Reinforce } \\
\text { concrete }\end{array}$ & $\bullet$ & & & $28 \%$ \\
\hline & $\begin{array}{c}\text { Corrugated } \\
\text { Steel }\end{array}$ & & $\bullet$ & & $48 \%$ \\
\hline & Others (thatch) & & & $\bullet$ & $2 \%$ \\
\hline
\end{tabular}

${ }^{1}$ Technical suitability determinants adapted from Federal Emergency Management Agency (FEMA) $[97,98]$.

\subsection{Building Clusters in the Study Area}

The previous sections have shown that there is a relationship between flood damage and the individual variables of building typology, age of the building, plinth height of the building, and type of building modifications. This section focuses on the relationships among multiple variables by identifying building clusters. Four variables provided the basis to identify building clusters in the study area. Three clusters emerged in the analysis with the ratio of the largest cluster to the smallest cluster being 1.32. The predictor importance of the variables for the clusters is: (i) Type of Damage due to flooding =1, (ii) Type of Transformed Parts of the House $=0.65$, (iii) Building Typology $=0.34$, and (iv) Age of the Building = 0.3. The Silhouette measure of cohesion and separation was fair (0.2).

The first cluster is composed of $89 \%$ of buildings with low damage from flooding; $75 \%$ of buildings that are less than 10 years old; $50 \%$ of building constructed with durable materials, and the predominant physical response to flood damage being raised homestead (29\%) or plinth modifications such as strengthened (36\%) or raised plinth height $(32 \%)$. The second cluster is characterized by a majority of buildings with medium flood damage (68\%) and constructed with durable materials (51\%). Most of the buildings in this cluster are between 10 and 20 years old (67\%), and the physical response strategy to flooding is predominantly strengthened walls $(54 \%)$. The third cluster comprises buildings that have high damage from flooding $(89 \%)$, constructed with natural materials (54\%), more than 20 years old $(63 \%)$, and the main physical flood response strategy being strengthening the whole building $(60 \%)$. Table 10 summarizes the components of the clusters. The clusters show that these variables interact to reflect the physical vulnerability of residents as measured by the extent of flood damage. 
Table 10. Components of the cluster analysis.

\begin{tabular}{|c|c|c|c|c|c|c|c|}
\hline \multirow{2}{*}{ Variables } & & \multicolumn{2}{|c|}{ Cluster 1} & \multicolumn{2}{|c|}{ Cluster 2} & \multicolumn{2}{|c|}{ Cluster 3} \\
\hline & & Count & $\%$ & Count & $\%$ & Count & $\%$ \\
\hline \multirow{4}{*}{ Damage due to Flooding } & Low Damage & 25 & 89 & 6 & 16 & 0 & 0 \\
\hline & Medium Damage & 3 & 11 & 25 & 68 & 4 & 11 \\
\hline & High Damage & 0 & 0 & 6 & 16 & 31 & 89 \\
\hline & Total & 28 & 100 & 37 & 100 & 35 & 100 \\
\hline \multirow{6}{*}{$\begin{array}{l}\text { Type of modifications of } \\
\text { the houses }\end{array}$} & Raised Homestead & 8 & 29 & 0 & 0 & 0 & 0 \\
\hline & Raised Plinth Level & 9 & 32 & 12 & 32 & 1 & 3 \\
\hline & Strengthened Plinth & 10 & 36 & 0 & 0 & 7 & 20 \\
\hline & Strengthened Walls & 0 & 0 & 20 & 54 & 6 & 17 \\
\hline & Strengthened Whole Building & 1 & 4 & 5 & 14 & 21 & 60 \\
\hline & Total & 28 & 100 & 37 & 100 & 35 & 100 \\
\hline \multirow{4}{*}{ Building Typology } & Buildings with Natural Materials (soil, bamboo, etc.) & 1 & 4 & 0 & 0 & 19 & 54 \\
\hline & Buildings with Temporary Materials (Metal, wood, etc.) & 13 & 46 & 18 & 49 & 7 & 20 \\
\hline & Buildings with Durable Material (Brick, Concrete, etc.) & 14 & 50 & 19 & 51 & 9 & 26 \\
\hline & Total & 28 & 100 & 37 & 100 & 35 & 100 \\
\hline \multirow{6}{*}{ Age of The Building } & $0-5$ years & 10 & 36 & 2 & 5 & 2 & 6 \\
\hline & 6-10 years & 11 & 39 & 10 & 27 & 3 & 9 \\
\hline & $11-15$ years & 2 & 7 & 9 & 24 & 2 & 6 \\
\hline & $16-20$ years & 0 & 0 & 6 & 16 & 6 & 17 \\
\hline & $21+$ years & 5 & 18 & 10 & 27 & 22 & 63 \\
\hline & Total & 28 & 100 & 37 & 100 & 35 & 100 \\
\hline
\end{tabular}




\section{Discussion}

In the Eastern periphery of Dhaka, residents experience different damages from flooding. These variations are influenced by statistically significant Cramer's V values that show that the type of building materials, age of buildings, and height of plinths affect the physical vulnerabilities of buildings in terms of the extent of damage from flooding. Households living in buildings made from natural materials such as wood and bamboo have a higher physical vulnerability to flooding compared to concrete and bricks. These observations align with similar studies in Limpopo, South Africa, where houses made of mud wall and thatched roof were severely damaged from floods [99,100]. This is because buildings with temporary materials are far less durable as they become wet and collapse during floods, requiring regular replacement after flood events [101]. Such damage can also be $35-50 \%$ higher compared to buildings that use bricks or concrete [102]. As evident from Table 5, 42.9\% of buildings with durable materials reported low damage compared to $5 \%$ of buildings with natural materials. Thus, it is apparent that during intense flood events with high volumes of water, the likelihood of flood damage would be greater among buildings constructed with natural and temporary materials compared to durable materials, as reported by Sagala [103].

This is crucial, particularly because not only does the use of materials that are easily damaged by flood increase building physical vulnerability, but they also increase the economic burden of those who live in them. Indeed, it is a common practice among residents vulnerable to flooding to save money and invest in rebuilding their houses or altering the building components (e.g., floor and wall materials) with relatively durable material. While savings on income is a strategic action undertaken by residents in flood-prone neighborhoods against the perennial damages of flood events [7], for many vulnerable places like eastern Dhaka, where the majority are low-income dwellers, strategies with long-term capacities to overcome physical vulnerability to flooding can provide some co-benefits by freeing up household savings that are spent on frequent building repairs. Furthermore, older buildings reportedly had a higher risk of flooding than newer buildings. Akin to other studies, older buildings are often weaker and make households more vulnerable during floods [104]. Since the age of buildings is a major indicator of extent and nature of flooding, it is imperative that households and city authorities pay attention to regular building maintenance to minimize risk of flooding. This will require partnerships with local artisans, education of residents, and making recommended maintenance strategies as part of proactive and comprehensive management plans to reduce vulnerabilities.

Amoako [43] reports that the absence of comprehensive and integrated disaster management plans in flood-prone neighborhoods hinders the adaptive capacity of communities in low-income areas. Additionally, such plans can be effective when community vulnerabilities and resilience capacities have been measured and mainstreamed into city and regional plans [105]. Hence, while the Dhaka Structure Plan expects private houses located at the eastern fringe of the city to employ floodwater management plans and strategies such as constructing building plinths to match the level of flood risk associated with the location of the building [106], this would be effective when residents and community partners are engaged in the implementation and enforcement processes. In the absence of community engagement, these expectations would be doubtful and unattainable [107] and undermine any efforts to ensure the long-term sustainability of physical adjustments to flood damage.

In eastern Dhaka, residents showed agency in dealing with their physical vulnerabilities to flooding by constructing plinths to deal with flooding. This is a community asset that the RAJUK (Rajdhani Unnayan Kartripakkha-the development authority of Dhaka city) can utilize to tackle physical vulnerability in the city. Insights from residents' agency—such as higher plinth reduce the damages of flooding both in the eastern Dhaka, and elsewhere [108,109], as well as mud and sand-cement for foundation and plinths are vulnerable to floods, if there is a prolonged flood event $[97,98,110]$ — can serve as the basis for innovative flood response strategies. Furthermore, residents' agency in dealing with their flood vulnerabilities is what some urban scholars working in the global south call incremental improvisations or adjustments [111-113]; here, residents begin from weak materials (e.g., mud), and gradually and progressively install or modify their buildings with stronger flood resistance materials 
(e.g., steel or concrete) as social and economic circumstances allow. In effect, the RAJUK can also design housing and flood management programs that can enable residents to incrementally adjust to and build resilience to flooding in Dhaka.

Particularly, and in relation to the above, this can be attained by targeting clusters of buildings with similar characteristics. In the analysis, three different clusters of buildings were identified. Typically, buildings that experience low flood damage are likely to be made of durable materials and are quite newly built (less than 10 years) with either strengthened and raised homestead and plinths. This cluster will evidently need a different intervention from clusters of buildings that experience high damage, predominantly constructed using natural materials, relatively older (above 20 years old), and characterized by strategies to strengthen their entire housing structure. The building clusters also provide an understanding of the limits of residents' flood response strategies in eastern Dhaka, which can enable planners to contextualize response strategies to suit specific buildings characteristics. From this perspective, this study transcends previous studies that provide a general outlook on grassroots responses to flood risks [7,43,72], to magnify the analytical lens to understand specific physical strategies and their structural limitations to reduce flood vulnerabilities in the long term.

\section{Conclusions}

Floods have increased the physical vulnerabilities of cities to disaster risks and have, therefore, become one of the threatening developmental problems of this era [114]. For those in Eastern Dhaka, flood remains a constant threat to livelihood and property in view of locational factors such as low surface elevation surrounded by the peripheral rivers. Infrastructure deficits further compound disaster risks in this urbanizing part of metropolitan Dhaka. This study analyzed three mahallas: Dhitpur, Tamburabad, and Nalsata, which are highly vulnerable to flooding. The study reveals that the extent of damage depended on the physical attributes such as building typology, age of the buildings, and height of the plinths. Buildings with durable materials, relatively newer buildings, and buildings with higher plinth levels experienced low damage from floods. On the other hand, buildings with natural materials, older buildings, and buildings with lower plinth levels had high damage during floods. Households have responded to their physical vulnerabilities by raising the homestead, raising and strengthening plinths, improving the condition of walls, and strengthening the whole building. Flood response strategies are primarily household-based, with very little initiatives at the community level.

Based on the above-mentioned findings, the following policy implications are identified. Community collective actions should be encouraged and strengthened to enhance the capacity of local people in organizing themselves before, during, and after the disaster, especially during floods. In this way, collective actions will provide a platform for collective learning, building, and exchange of knowledge from diverse context-specific experiences [115]. There is also a need to enhance household level flood strategies before, during and after flooding events to improve local capacity to deal with physical flood vulnerabilities. Local-level support from the government needs to be facilitated by professionals from Bangladesh's Department of Disaster Management and Housing and Building Research Institute to educate local people and artisans on disaster-resilient building techniques and improve their skills in flood-resistant construction, as was done in the Philippines [116]. Finally, effective communication of flood risk management strategies and plans to households can ensure disaster preparedness in flood-prone communities [117,118]. Here, flood risks and disaster management plans should be tailored to the contextual realities of flood victims, with due cognizance to literacy levels, socio-economic profiles, and other cultural idiosyncrasies.

This study contributes to the current literature in two ways. Firstly, most of the previous studies on the flood vulnerability and damage assessment in Bangladesh focused on macro-level (national level or city level). Micro-level approaches (community-specific) have received little attention, barring few exceptions $[7,56]$, more so in peri-urban eastern Dhaka where there is both scant data and limited formal planning and management [118]. In this vein, this paper provides avenues for co-production and co-learning opportunities between local citizens and institutions towards flood management 
planning by unearthing local competencies and experiences from the aspect of residential buildings. Secondly, apart from using traditional socio-economic indicators, this study considered physical vulnerability indicators to verify their relationships with the damage extent due to flooding in the context of peri-urban areas in the eastern fringe of Dhaka. However, it needs mentioning that given the small geographical setting and the sample size, the findings of this study are not meant to be definitive or generalized, rather to provide exploratory insights into the interconnections between flood vulnerability, building damage, and local adjustments in low-income settings as entry points for identifying key areas for building local resilience and adaptive capacity. Future research may need to consider expanding sample sizes in a relatively large geographical scale, in addition to in-depth hydrological and hydraulic sensitivity analyses for a comprehensive understanding of flood exposure and vulnerabilities.

Author Contributions: Conceptualization: M.N.F., S.A.O., S.K.D., M.K., M.S., and S.M.; formal analysis: M.N.F., S.A.O., S.K.D., and M.K.; investigation: M.N.F.; methodology: M.N.F., S.A.O., S.K.D., and M.K.; visualization: M.N.F.; writing—original draft: M.N.F., S.A.O., S.K.D., M.K., M.S., and S.M.; writing一review and editing: M.N.F., S.A.O., S.K.D., M.K., M.S., and S.M. All authors have read and agreed to the published version of the manuscript.

Acknowledgments: We thank the respondents of Dhitpur, Tamburabad and Nalsata for their help and assistance during the survey.

Conflicts of Interest: The authors declare no conflict of interest.

\section{References}

1. UN-HABITAT. Pro-Poor Urban Climate Resilience in Asia and the Pacific; United Nations Human Settlements Programme (UN-HABITAT): Nairobi, Kenya, 2014.

2. Satterthwaite, D.; Bicknell, J.; Dodman, D. Adapting to Climate Change in Urban Areas. In Adapting Cities to Climate Change Understanding and Addressing the Development Challenges; Bicknell, J., Dodman, D., Satterthwaite, D., Eds.; International Institute for Environment and Development (IIED): London, UK, 2009.

3. Danso, S.Y.; Addo, I.Y. Coping strategies of households affected by flooding: A case study of Sekondi-Takoradi Metropolis in Ghana. Urban Water J. 2017, 14, 539-545. [CrossRef]

4. ProAct. Climate Change Adaptation and Disaster Risk Reduction; ProAct Network (ProAct): Nyon, Switzerland, 2008.

5. IPU. Disaster Risk Reduction: An Instrument for Achieving the Millennium Development Goals: Advocacy Kit for Parliamentarians; International Strategy for Disaster Reduction (UNISDR), IPU: Geneva, Switzerland, 2010.

6. Nji, T.M.; Balgah, R.A. Determinants of Coping Strategies to Floods and Droughts in Multiple Geo-Ecological Zones. In Natural Hazards; IntechOpen: London, UK, 2019.

7. Jabeen, H.; Johnson, C.; Allen, A. Built-in resilience: Learning from grassroots coping strategies for climate variability. Environ. Urban 2010, 22, 415-431. [CrossRef]

8. Wamsler, C. Bridging the gaps: Stakeholder-based strategies for risk reduction and financing for the urban poor. Environ. Urban 2007, 19, 115-142. [CrossRef]

9. Huq, S.; Reid, H. Community-Based Adaptation: A Vital Approach to the Threat Climate Change Poses to the Poor; International Institute for Environment and Development: London, UK, 2007.

10. Smith, K. Environmental Hazards: Assessing Risk and Reducing Disaster; Routledge: Abingdon, UK, 2003.

11. Cutter, S.L.; Barnes, L.; Berry, M.; Burton, C.; Evans, E.; Tate, E.; Webb, J. A place-based model for understanding community resilience to natural disasters. Global Environ. Chang. 2008, 18, 598-606. [CrossRef]

12. Cutter, S.L.; Mitchell, J.T.; Scott, M.S. Revealing the vulnerability of people and places: A case study of Georgetown County, South Carolina. Ann. Assoc. Am. Geogr. 2000, 90, 713-737. [CrossRef]

13. Mucke, P. World Risk Report 2018; Bundnis Entwicklung Hilft: Berlin, Germany, 2018.

14. Ahmed, A.M.M.M.; Roy, K. Utilization and conservation of water resources in Bangladesh. J. Dev. Sustain. Agric. 2007, 2, 35-44.

15. UN. World Population Prospects 2019_Volume II: Demographic Profiles; Department of Economic and Social Affairs, Population Division, United Nations (UN): New York, NY, USA, 2019.

16. Ferdous, M.R.; Wesselink, A.; Brandimarte, L.; Slager, K.; Zwarteveen, M.; Di Baldassarre, G. The Costs of Living with Floods in the Jamuna Floodplain in Bangladesh. Water 2019, 11, 1238. [CrossRef] 
17. Shajahan, A.; Reja, M.Y. Towards Sustainable Flood Mitigation Strategies: A Case Study of Bangladesh. In Disaster, Risk and Vulnerability Conference 2011; Mahatma Gandhi University: Kerala, India, 2011.

18. UN. World Urbanization Prospects: The 2018 Revision; Department of Economic and Social Affairs, Population Division, United Nations (UN): New York, NY, USA, 2018.

19. Lamb, Z. Embanked: Climate Vulnerability and the Paradoxes of Flood Protection in Dhaka; Department of Urban Studies and Planning, Massachusetts Institute of Technology: Cambridge, MA, USA, 2014.

20. Bird, J.; Li, Y.; Rahman, H.Z.; Rama, M.; Venables, A.J. Toward Great Dhaka: A New Urban Development Paradigm Eastward; The World Bank: Washington, DC, USA, 2018.

21. Hallegatte, S.; Green, C.; Nicholls, J.R.; Corfee-Morlot, J. Future flood losses in major coastal cities. Nat. Clim. Chang. 2013, 3, 802. [CrossRef]

22. Jha, A.K.; Bloch, R.; Lamond, J. Cities and Flooding: A Guide to Integrated Urban Flood Risk Management for the 21st Century; The World Bank: Washington, DC, USA, 2012.

23. Ouma, Y.; Tateishi, R. Urban flood vulnerability and risk mapping using integrated multi-parametric AHP and GIS: Methodological overview and case study assessment. Water 2014, 6, 1515-1545. [CrossRef]

24. Jonkman, S.; Dawson, R. Issues and challenges in flood risk management-Editorial for the special issue on flood risk management. Water 2012, 4, 785-792. [CrossRef]

25. Bates, P.D.; De Roo, A. A simple raster-based model for flood inundation simulation. J. Hydrol. 2000, 236, 54-77. [CrossRef]

26. Birkmann, J. Measuring Vulnerability to Promote Disaster-Resilient Societies: Conceptual Frameworks and Definitions. In Measuring Vulnerability to Natural Hazards: Towards Disaster Resilient Societies; Birkmann, J., Ed.; United Nations University Press: Tokyo, Japan, 2006; pp. 9-54.

27. Salami, R.O.; Von Meding, J.K.; Giggins, H. Vulnerability of human settlements to flood risk in the core area of Ibadan metropolis, Nigeria. Jàmbá J. Dis. Risk Stud. 2017, 9, 1-14. [CrossRef] [PubMed]

28. Gallopín, G.C. Linkages between vulnerability, resilience, and adaptive capacity. Glob. Environ. Chang. 2006, 16, 293-303. [CrossRef]

29. Berkes, F.; Colding, J.; Folke, C. Navigating Social-Ecological Systems: Building Resilience for Complexity and Change; Cambridge University Press: Cambridge, UK, 2008.

30. Twum, K.O.; Abubakari, M. Cities and floods: A pragmatic insight into the determinants of households' coping strategies to floods in informal Accra, Ghana. Jàmbá J. Dis. Risk Stud. 2019, 11,1-14.

31. Formetta, G.; Feyen, L. Empirical evidence of declining global vulnerability to climate-related hazards. Glob. Environ. Chang. 2019, 57, 101920. [CrossRef]

32. Wisner, B.; Davis, I.; Cannon, T.; Blaikie, P. At Risk: Natural Hazards, People's Vulnerability and Disasters, 2nd ed.; Routledge: London, UK, 2003.

33. IPCC. Climate Change 2001: The Scientific Basis; Contribution of Working Group I to the Third Assessment Report of the Intergovernmental Panel on Climate Change; Houghton, J., Ding, J., Griggs, D.J., Noguer, M., van der Linden, P.J., Dai, X., Maskell, K., Johnson, C.A., Eds.; Cambridge University Press: Cambridge, UK, 2001; p. 881.

34. Few, R. Flooding, vulnerability and coping strategies: Local responses to a global threat. Prog. Dev. Stud. 2003, 3, 43-58. [CrossRef]

35. Fuchs, S. Cost-Benefit Analysis of Natural Hazard Mitigation. In Encyclopedia of Natural Hazards; Bobrowski, P., Ed.; Springer: Dordrecht, The Netherlands, 2013; pp. 121-125.

36. Papathoma-Köhle, M.; Kappes, M.; Keiler, M.; Glade, T. Physical vulnerability assessment for alpine hazards: State of the art and future needs. Nat. Hazards 2011, 58, 645-680. [CrossRef]

37. Kappes, M.S.; Papathoma-Koehle, M.; Keiler, M. Assessing physical vulnerability for multi-hazards using an indicator-based methodology. Appl. Geogr. 2012, 32, 577-590. [CrossRef]

38. WB. The Caribbean Handbook for Risk Information Management (CHARIM); EU-funded ACP-EU Natural Disaster Risk Reduction Program, Ed.; World Bank (WB): Washington, DC, USA, 2014.

39. Blanco, A.; Schanze, J. Conceptual and methodological frameworks for large scale and high resolution analysis of the physical flood vulnerability of buildings. In Comprehensive Flood Risk Management-Research for Policy and Practice; Klijn, F., Schweckendiek, T., Eds.; CRC Press: Rotterdam, The Netherlands, 2012; pp. 591-598. 
40. Yankson, P.W.K.; Owusu, A.B.; Owusu, G.; Boakye-Danquah, J.; Tetteh, J.D. Assessment of coastal communities' vulnerability to floods using indicator-based approach: A case study of Greater Accra Metropolitan Area, Ghana. Nat. Hazards 2017, 89, 661-689. [CrossRef]

41. Westen, C.J.V. Vulnerability. 2014. Available online: http://www.charim.net/methodology/53 (accessed on 9 May 2019).

42. Westen, C.J.V. Remote sensing and GIS for natural hazards assessment and disaster risk management. Treatise Geomorphol. 2013, 3, 259-298.

43. Amoako, C. Emerging grassroots resilience and flood responses in informal settlements in Accra, Ghana. GeoJournal 2018, 83, 949-965. [CrossRef]

44. Renaud, F.G.; Birkmann, J.; Damm, M.; Gallopín, G.C. Understanding multiple thresholds of coupled social-ecological systems exposed to natural hazards as external shocks. Nat. Hazards 2010, 55, 749-763. [CrossRef]

45. Satterthwaite, D. Climate change and urbanization: Effects and implications for urban governance. In United Nations Expert Group Meeting on Population Distribution, Urbanization, Internal Migration and Development; DESA: New York, NY, USA, 2008.

46. UNISDR. 2009 UNISDR Terminology on Disaster Risk Reduction; United Nations International Strategy for Disaster Reduction (UNISDR), United Nations: Geneva, Switzerland, 2009; pp. 1-35.

47. Wamsler, C.; Lawson, N. Complementing institutional with localised strategies for climate change adaptation: A South-North comparison. Disasters 2012, 36, 28-53. [CrossRef] [PubMed]

48. Birkmann, J. Regulation and coupling of society and nature in the context of natural hazards. In Coping with Global Environmental Change, Disasters and Security; Brauch, H., Ed.; Springer: Berlin, Germany, 2011; pp. 1103-1127.

49. Pelling, M. Adaptation to Climate Change: From Resilience to Transformation; Routledge: London, UK, 2010.

50. IPCC. Climate Change 2007-Impacts, Adaptation and Vulnerability; Working group II contribution to the fourth assessment report of the IPCC, Parry, M., Canziani, O.F., Palutikof, J.P., van der Linden, P.J., Hanson, C.E., Eds.; Cambridge University Press: Cambridge, UK, 2007; Volume 4.

51. Stephens, C.; Patnaik, R.; Lewin, S. This Is My Beautiful Home: Risk Perceptions Towards Flooding and Environment in Low-Income Urban Communities: A Case Study in Indore, India; London School of Hygiene and Tropical Medicine: London, UK, 1996; Volume 51, pp. 187-205.

52. Schmuck-Widmann, H. Living with the Floods: Survival Strategies of Char-Dwellers in Bangladesh; LN-Vertrieb: Berlin, Germany, 1996.

53. Rashid, S.F. The urban poor in Dhaka City: Their struggles and coping strategies during the floods of 1998. Disasters 2000, 24, 240-253. [CrossRef]

54. Sanderson, D. Cities, disasters and livelihoods. Risk Manag. 2000, 2, 49-58. [CrossRef]

55. Wamsler, C.; Brink, E. Moving beyond short-term coping and adaptation. Environ. Urban 2014, 26, 86-111. [CrossRef]

56. Paul, S.K.; Routray, J.K. Flood proneness and coping strategies: The experiences of two villages in Bangladesh. Disasters 2010, 34, 489-508. [CrossRef]

57. Tacoli, C. The links between urban and rural development. Environ. Urban 2003, 15, 3-12. [CrossRef]

58. Ricci, L. Peri-urban livelihood and adaptive capacity: Urban development in Dar Es Salaam. Cons. J. Sustain. Dev. 2012, 7, 46-63.

59. Allen, A.; Dávila, J.D.; Hofmann, P. Governance of Water and Sanitation Services for the Peri-Urban Poor: A Framework for Understanding and Action in Metropolitan Regions; The Bartlett Development Planning Unit: London, UK, 2006.

60. Eakin, H.; Lerner, A.M.; Murtinho, F. Adaptive capacity in evolving peri-urban spaces: Responses to flood risk in the Upper Lerma River Valley, Mexico. Glob. Environ. Chang. 2010, 20, 14-22. [CrossRef]

61. Douglas, I.; Alam, K.; Maghenda, M.; Mcdonnell, Y.; Mclean, L.; Campbell, J. Unjust waters: Climate change, flooding and the urban poor in Africa. Environ. Urban 2008, 20, 187-205. [CrossRef]

62. Winsemius, H.C.; Jongman, B.; Veldkamp, T.I.E.; Hallegatte, S.; Bangalore, M.; Ward, P.J. Disaster risk, climate change, and poverty: Assessing the global exposure of poor people to floods and droughts. Environ. Dev. Econ. 2018, 23, 328-348. [CrossRef] 
63. Grasham, C.F.; Korzenevica, M.; Charles, K.J. On considering climate resilience in urban water security: A review of the vulnerability of the urban poor in sub-Saharan Africa. Wiley Interdiscip. Rev. Water 2019, 6, 1-11. [CrossRef]

64. Edoun, E.I.; Balgah, R.A.; Mbohwa, C. The impact of effective management of natural disasters For Africa's development. Econ. Res.-Ekonomska Istraživanja 2015, 28, 924-938. [CrossRef]

65. Berman, R.J.; Quinn, C.H.; Paavola, J. Identifying drivers of household coping strategies to multiple climatic hazards in Western Uganda: Implications for adapting to future climate change. Clim. Dev. 2015, 7, 71-84. [CrossRef]

66. Balgah, R.A.; Bang, H.N.; Fondo, S.A. Drivers for coping with flood hazards: Beyond the analysis of single cases. Jàmbá J. Dis. Risk Stud. 2019, 11, 1-9. [CrossRef]

67. Ciurean, R.L.; Schröter, D.; Glade, T. Conceptual frameworks of vulnerability assessments for natural disasters reduction. In Approaches to Disaster Management-Examining the Implications of Hazards, Emergencies and Disasters; Tiefenbacher, J., Ed.; IntechOpen: London, UK, 2013.

68. Davis, I. Progress in analysis of social vulnerability and capacity. In Mapping Vulnerability: Disasters, Development and People; Bankoff, G., Frerks, G., Hilhorst, D., Eds.; Routledge: Abingdon, UK, 2013; pp. 147-163.

69. Moser, C.; Satterthwaite, D. Toward pro-poor adaptation to climate change in the urban centers of low-and middle-income countries. In Social Dimensions of Climate Change: Equity and Vulnerability in a Warming World; Mearns, E., Norton, A., Eds.; The World Bank: Washington, DC, USA, 2010; pp. 231-258.

70. Tarbotton, C.; Dall'osso, F.; Dominey-Howes, D.; Goff, J. The use of empirical vulnerability functions to assess the response of buildings to tsunami impact: Comparative review and summary of best practice. Earth-Sci. Rev. 2015, 142, 120-134. [CrossRef]

71. Schwarz, A.-M.; Béné, C.; Bennett, G.; Boso, D.; Hilly, Z.; Paul, C.; Posala, R.; Sibiti, S.; Andrew, N. Vulnerability and resilience of remote rural communities to shocks and global changes: Empirical analysis from Solomon Islands. Glob. Environ. Chang. 2011, 21, 1128-1140. [CrossRef]

72. Owusu-Ansah, J.K.; Dery, J.M.; Amoako, C. Flood vulnerability and coping mechanisms around the Weija Dam near Accra, Ghana. GeoJournal 2019, 84, 1597-1615. [CrossRef]

73. Morse, J.M. Approaches to qualitative-quantitative methodological triangulation. Nurs. Res. 1991, 40, 120-123. [CrossRef]

74. Creswell, J.W.; Clark, V.L.P. Designing and Conducting Mixed Methods Research; Sage Publications: New York, NY, USA, 2018.

75. Tanoue, M.; Hirabayashi, Y.; Ikeuchi, H. Global-scale river flood vulnerability in the last 50 years. Sci. Rep. 2016, 6, 36021. [CrossRef]

76. IPCC. UN Climate Change Chief Christiana Figueres! Latest IPCC Findings Point to Extreme Climate Change Risk: Plethora of Opportunities for Climate Action; Intergovernmental Panel on Climate Change (IPCC), United Nations Climate Change Secretariat: Bonn, Germany, 2014.

77. Luo, T.; Maddocks, A.; Iceland, C.; Ward, P.; Winsemius, H. World's 15 Countries with the Most People Exposed to River Floods; World Resources Institute: Washington, DC, USA, 2015; Volume 5.

78. Yu, W.H.; Alam, M.; Hassan, A.; Khan, A.S.; Ruane, A.C.; Rosenzweig, C.; Major, D.; Thurlow, J. Climate Change Risks and Food Security in Bangladesh; Routledge: London, UK, 2010.

79. Braun, B.; Aßheuer, T. Floods in megacity environments: Vulnerability and coping strategies of slum dwellers in Dhaka/Bangladesh. Nat. Hazards 2011, 58, 771-787. [CrossRef]

80. Dasgupta, S.; Zaman, A.M.; Roy, S.; Huq, M.; Jahan, S.; Nishat, A. Urban Flooding of Greater Dhaka in a Changing Climate: Building Local Resilience to Disaster Risk; World Bank: Washington, DC, USA, 2015.

81. Dewan, A.M.; Islam, M.M.; Kumamoto, T.; Nishigaki, M. Evaluating flood hazard for land-use planning in Greater Dhaka of Bangladesh using remote sensing and GIS techniques. Water Resour. Manag. 2007, 21, 1601-1612. [CrossRef]

82. Nilufar, F. Urban morphology of Dhaka city: Spatial dynamics of growing city and the urban core. In International Seminar on The History, Heritage and Urban Issues of Capital Dhaka, on the Occasion of the Celebration of 400 Years of the Capital Dhaka; Asiatic Society of Bangladesh: Dhaka, Bangladesh, 2010.

83. Islam, I. Wetlands of Dhaka Metro Area: A Study from Social, Economic, and Institutional Perspectives; AH Development Publishing House: Dhaka, Bangladesh, 2009.

84. JICA. Master Plan for Greater Dhaka Protection Project of Bangladesh Flood Action Plan No. 8A: FAP 8A; Japan International Cooperation Agency (JICA), Flood Plan Coordination Agency: Dhaka, Bangladesh, 1992. 
85. Kamal, M. GIS Based Flood Risk Assessment: A Case Study on Three Wards of Dhaka City. In Dhaka Metropolitan Development Area and Its Planning: Problem, Issues and Policies; Jahan, S., Kalam, A.K.M.A., Eds.; Bangladesh Institute of Planners (BIP): Dhaka, Bangladesh, 2013; pp. 181-199.

86. Schneiderbauer, S. Risk and Vulnerability to Natural Disasters from Broad View to Focused Perspective: Theoretical Background and Applied Methods for the Identification of the Most Endangered Populations in Two Case Studies at Different Scales; Freie Universität Berlin: Berlin, Germany, 2007.

87. Taubenböck, H.; Wurm, M.; Netzband, M.; Zwenzner, H.; Roth, A.; Rahman, A.; Dech, S. Flood risks in urbanized areas-multi-sensoral approaches using remotely sensed data for risk assessment. Nat. Hazards Earth Syst. Sci. 2011, 11, 431. [CrossRef]

88. Gain, A.K.; Mojtahed, V.; Biscaro, C.; Balbi, S.; Giupponi, C. An integrated approach of flood risk assessment in the eastern part of Dhaka City. Nat. Hazards 2015, 79, 1499-1530. [CrossRef]

89. Müller, A.; Reiter, J.; Weiland, U. Assessment of urban vulnerability towards floods using an indicator-based approach-A case study for Santiago de Chile. Nat. Hazards Earth Syst. Sci. 2011, 11, 2107-2123. [CrossRef]

90. Laurien, F.; Hochrainer-Stigler, S.; Keating, A.; Campbell, K.; Mechler, R.; Czajkowski, J. A typology of community flood resilience. Reg. Environ. Chang. 2020, 20, 1-14. [CrossRef]

91. Wahab, R.; Tiong, R. Multi-variate residential flood loss estimation model for Jakarta: An approach based on a combination of statistical techniques. Nat. Hazards 2017, 86, 779-804. [CrossRef]

92. BBS. Bangladesh Statistics 2017; Bangladesh Bureau of Statistics (BBS), Ministry of Planning, Government of the People's Republic of Bangladesh: Dhaka, Bangladesh, 2017.

93. CIA. The World Factbook; Central Intelligence Agency (CIA): Washington, DC, USA, 2018.

94. Lee, S.; Okazumi, T.; Kwak, Y.; Takeuchi, K. Vulnerability proxy selection and risk calculation formula for global flood risk assessment: A preliminary study. Water Policy 2015, 17, 8-25. [CrossRef]

95. Shah, A.A.; Ye, J.; Abid, M.; Ullah, R. Determinants of flood risk mitigation strategies at household level: A case of Khyber Pakhtunkhwa (KP) province, Pakistan. Nat. Hazards 2017, 88, 415-430. [CrossRef]

96. Green, C.; van der Veen, A.; Wierstra, E.; Penning-Rowsell, E. Vulnerability refined: Analysing full flood impacts. In Floods Across Europe; Penning-Rowsell, E.C., Fordham, M., Eds.; Middelsex University Press: London, UK, 1994; pp. 32-68.

97. FEMA. Flood Damage-Resistant Materials-Requirements for Buildings Located in Special Flood Hazard Areas in Accordance with the National Flood Insurance Program; Federal Emergency Management Agency (FEMA): Washington, DC, USA, 2008.

98. Sakijege, T.; Sartohadi, J.; Marfai, M.A.; Sakijege, T.; Kassenga, G.R.; Kasala, S.E. Assessment of adaptation strategies to flooding: A comparative study between informal settlements of Keko Machungwa in Dar es Salaam, Tanzania and Sangkrah in Surakarta, Indonesia. Jàmbá J. Dis. Risk Stud. 2014, 6, 1-10. [CrossRef]

99. Khandlhela, M.; May, J. Poverty, vulnerability and the impact of flooding in the Limpopo Province, South Africa. Nat. Hazards 2006, 39, 275-287. [CrossRef]

100. Maiti, S. Defining a Flood Risk Assessment Procedure Using Community Based Approach with Integration Of Remote Sensing and GIS, Based on The 2003 Orissa Flood; International Institute for Geo-Information Science and Earth Observation (ITC): Enschede, The Netherlands, 2007.

101. Englhardt, J.; De Moel, H.; Huyck, C.K.; de Ruiter, M.C.; Aerts, J.C.J.H.; Ward, P.J. Enhancement of large-scale flood damage assessments using building-material-based vulnerability curves for an object-based approach. Nat. Hazard Earth Syst. Sci. 2019, 19, 1-28. [CrossRef]

102. Buck, W. Die neue DWA-Arbeitshilfe "Hochwasserschadensinformationen". In Fünf Jahre nach der Flut. Hochwasserschutzkonzepte_Planung, Berechnung, Realisierung. Dresdner Wasserbaukolloquium, 8-9 Oktober 2007; Horlacher, H.B., Ed.; IWD: Dresden, Germany, 2007; pp. 95-103.

103. Sagala, S.A.H. Analysis of flood physical vulnerability in residential areas, Case study: Naga City, The Philippines. In International Institute for Geo-Information Science and Earth Observation; University of Twente: Enschede, The Netherlands, 2006.

104. Rana, I.A.; Routray, J.K. Multidimensional model for vulnerability assessment of urban flooding: An empirical study in Pakistan. Int. J. Dis. Risk Sci. 2018, 9, 359-375. [CrossRef]

105. Laurien, F.; Keating, A. Evidence from Measuring Community Flood Resilience in Asia; Asian Development Bank: Mandaluyong, Philippines, 2019.

106. RAJUK. Dhaka Structure Plan 2016-2035; Rajdhani Unnayan Kartripakkha (RAJUK), Ministry of Housing and Public Works, Government of the People's Republic of Bangladesh: Dhaka, Bangladesh, 2015. 
107. Mowla, Q.A. The Proposed Dhaka Structure Plan 2016-2035; The Independent: Dhaka, Bangladesh, 2015.

108. Takeuchi, Y.; Shaw, R. Traditional flood disaster reduction measures in Japan. In Indigenous Knowledge for Disaster Risk Reduction; Shaw, R., Uy, N., Baumwoll, J., Eds.; UNISDR: Bangkok, Thailand, 2008; pp. $23-26$.

109. Zin, W.W.; Kawasaki, A.; Takeuchi, W.; Mar Lar Tin San, Z.; Zaya Htun, K.; Hnin Aye, T.; Win, S. Flood Hazard Assessment of Bago River Basin, Myanmar. J. Dis. Res. 2018, 13, 14-21. [CrossRef]

110. UN-HABITAT. Pakistan Settlements Flood Recovery Project (PSFRP); United Nations Human Settlement Programme (UN-Habitat), United Nations: Fukuoka, Japan, 2015.

111. Kita, M.; Okyere, S.A.; Sugita, M.; Diko, S.K. In Search of Place and Life in Indigenous Urban Communities: An Exploration of Abese Indigenous Quarter of La Dadekotopon, Accra. In The Challenge of African Potentials: Conviviality, Informality and Futurity; Langaa RPCIG: Bamenda, Cameroon, 2020; p. 87.

112. Okyere, S.A.; Diko, S.K.; Hiraoka, M.; Kita, M. An Urban "Mixity": Spatial Dynamics of Social Interactions and Human Behaviors in the Abese informal Quarter of La Dadekotopon, Ghana. Urban Sci. 2017, 1, 13. [CrossRef]

113. Silver, J. Incremental infrastructures: Material improvisation and social collaboration across post-colonial Accra. Urban Geogr. 2014, 35, 788-804. [CrossRef]

114. Pelling, M. The Vulnerability of Cities: Natural Disasters and Social Resilience; Routledge: Abingdon, UK, 2012.

115. Lebel, L.; Anderies, J.M.; Campbell, B.; Folke, C.; Hatfield-Dodds, S.; Hughes, T.P.; Wilson, J. Governance and the capacity to manage resilience in regional social-ecological systems. Ecol. Soc. 2006, 11, 21. [CrossRef]

116. Luansang, C.S.; Boonmahathanakorn, M.L. Domingo-Price. The Role of Community Architects in Upgrading; Reflecting on the Experience in Asia. Environ. Urban 2012, 24, 497-512. [CrossRef]

117. Abunyewah, M.; Gajendran, T.; Maund, K.; Okyere, S.A. Linking information provision to behavioural intentions. Int. J. Dis. Resil. Built Environ. 2019, 11, 100-118. [CrossRef]

118. Abunyewah, M.; Gajendran, T.; Maund, K.; Okyere, S.A. Strengthening the information deficit model for disaster preparedness: Mediating and moderating effects of community participation. Int. J. Dis. Risk Reduct. 2020, 46, 101492. [CrossRef]

(C) 2020 by the authors. Licensee MDPI, Basel, Switzerland. This article is an open access article distributed under the terms and conditions of the Creative Commons Attribution (CC BY) license (http://creativecommons.org/licenses/by/4.0/). 